\title{
Sex expression of date palm (Phoenix Dactylifera L.) trees in relation to some leaf chemical constituents
}

\begin{abstract}
This investigation was carried out during the successive seasons of 2015, 2016 and 2017 using nine years old date palm trees of "Amhat" cultivar grown in clay soil located at Al-aelam Fayoum Governorate, Egypt. The objective of this study was to predict sex of date palm through some leaf chemical constituents. Generally, it was found that there are great differences in chemical constituents of pinnae, i.e. chlorophyll a \& b, total caroteniods, total anthocyanin, total carbohydrates, total and reducing sugars, total free amino acids, free proline, total indoles, nitrogen, crude protein, total phenols, dry matter, ash and silicon between male and female date palm c.v "Amhat". Female trees were characterized by the increase in the concentration of chlorophyll a \& b, total caroteniods, total anthocyanin, total carbohydrates, total and reducing sugars, total free amino acids, total indoles, nitrogen, crude protein, total phenols, dry matter and silicon over male trees. On the contrary, male trees were characterized by the increase in the concentration of ash and proline over female trees. From the obtained results, it has been concluded that female date palm plants was characterized by high capacity to anabolism and the accumulation of these substances resulting from these processes and vice versa in pinnae of male date palm plants. These pinnae chemical analysis can be used as a mean for predicting sex in date palm plant "Amhat" cultivar.
\end{abstract}

Keywords: date palm (phoenix dactylifera $\mathrm{L}$.), sex determination, pinnae chemical constituents
Volume 2 Issue 6 - 2018

\author{
Mohamed A Seif El-Yazal \\ Department of Botany, Faculty of Agriculture, Fayoum University, \\ Egypt
}

Correspondence: Mohamed A Seif El-Yazal, Department of Botany, Faculty of Agriculture, Fayoum University, Egypt, Emailmes04@fayoum.edu.eg

Received: October 08, 2018 | Published: December 10, 2018

\section{Introduction}

Date palm (Phoenix dactylifera $\mathrm{L}$.) is one of the oldest fruit crops grown in the arid regions of the Arabian Peninsula, North Africa, and the Middle East. Dates are a major food source and income source for local populations in the Middle East and North Africa, and play significant roles in the economy, society, and environment in these areas. In addition to serving directly as a food source, dates are packed and processed in a number of ways, and other parts of the tree are used for various purposes. The date palm is a diploid, perennial, dioeciously, and monocotyledonous plant adapted to arid environments. It has unique biological and developmental characteristics that necessitate special propagation, culture, and management techniques. Thousands of date palm cultivars and selections exist in different date-growing countries. "Amhat" is one of the most important cultivars of soft dates in Egypt especially in Fayoum Governorate where it is considered as the most common cultivar widely grown in such Governorate and can grow and produce under a wide range of soil and climatic conditions; growers have mistakenly believed that it does not require much attention. ${ }^{2}$ Currently there is no reliable method to identify sex at the early seedling stage. Early sex identification of young seedlings could enhance breeding programs and generate experimental male and female genetic stocks that will help the genetic improvement of the date palm. Moreover, the selection and identification of superior seedling characters for yield enhancement and to improve the physical and chemical properties of fruits is of great commercial interest. There has been significant progress in our understanding of sex-determining mechanisms in date palm using traditional means. But physiological and cytological methods do not give obvious differences between male and female date palms. Biotechnology, as a new tool in date palm breeding, can be useful to improve the qualities of palm trees through early sex identification. Although molecular markers have been introduced in date palm programs, few research efforts have been geared toward studying the early sex determination in the plant. ${ }^{3}$

On the other hand, date palm is a dioeciously plant and one male is sufficient to ensure perfect pollination for twenty female palms. Thereupon, the growth and development of offsets into male palms, which are detected only at fruiting stage (after seven years from planted) are considered not only useless plants, but also a great loss from the commercial point of view. Consequently the determination of sex in date palm in early stage of growth is very important from the commercial point of view. Several investigators studied the differences between male and female papaya (Carica papaya L.) trees i.e. ${ }^{4-7}$ by using also the chemical analysis of leaves. On the other hand, Little investigators studied the differences between male and female date palms (Phoenix dactylifera $\mathrm{L}$.) trees by using the chemical analysis of leaves and sap such $\mathrm{as}^{8-13}$ on date palms.

Sugar was the major constituent in both male and female date palm sap, which is consistent with the fndings reported for the sap from Phoenix sylvestris and Borassus flabellifer. ${ }^{14}$ Compared to male date palm sap, female palm sap exhibited higher levels of sugar content. Moreover, the male date palm sap contained lower dry matter content than the female date palm sap. The male date palm sap exhibited higher total phenolic content than the female (2.04 vs.1.648 $\mu \mathrm{g}$ gallic acid equivalent $\mathrm{mL}-1$ of total polyphenol, respectively). ${ }^{13}$ Plant sex may affect the quality of the sap (Phoenix dactylifera L.). This result is in agreement with previous reports on sap from the Borassus flabellifer palm in Borma, where up to six qualities of sap were differentiated based on the tapping stage and plant sex. ${ }^{15}$ Also,,${ }^{13}$ pointed out that male sap dry matter content was higher than that of the female. It decreased significantly through the tapping period. During the harvest, the male sap protein content decreased but increased significantly in the female 
sap. Finally, sugar fraction, for both male and female DN sap, was dominated by sucrose, glucose, fructose, and a small amount of myoinositol. During the collection time, sugar content is affected by the sex especially for myo-inositol content that increased significantly in the female date sap, unlike that of the male one. This may be related to the fact that the male palm is more resistant to physiological stress, inducing myo-inositol formation during tapping.

Accordingly, the present investigation was carried out to predict sex of date palm through detecting the relationship between some leaf chemical constituents and sex expression of date palm trees during 2015,2016 and 2017 seasons by the aim to separate the male offsets from female ones early in nursery before cultivation inpermanent orchard, where about $50 \%$ from offsets come from seeds were male offsets.

\section{Materials and methods}

The present investigation was conducted during three successive seasons 2015, 2016 and 2017 on date palm trees of "Amhat" cultivar grown in clay soil located at Al-aelam, Fayoum Governorate, Egypt. The objective was to get some information about the relationship between sex expression of "Amhat" date palm and some leaf chemical constituents. The experimental palms were healthy, as they were uniform in growth, vigour and height and received all cultural practices according to the traditional schedule for experimental palms. The presented experiment contained 20 trees of both female and male date palm. The trees were nine year old, newly emerged leaf was selected from each palm, samples consists of five leaves from each tree and from each leaf ten pinnae were taken by detaching five pinnae from each side of the mid-portion rachis of male and female leaves. Leaflets samples were taken during November of all seasons and washed with tap water and then with distilled water to remove the dust and any chemical spray residues. After washing, samples were used fresh or dry (the samples were dried in an electric over at $70 \mathrm{C}^{0}$ \pm 2 till constant weight, then finely ground).

\section{Chemical constituents}

Numbers of the following chemical constituents were determined in fresh pinnae and the other in the powdered dry pinnae.

\section{Photosynthetic pigments:}

The photosynthetic pigments (chlorophyll $\mathrm{a} \& \mathrm{~b}$ as well as total caroteniods) were extracted by homogenizing $0.5 \mathrm{gm}$ fresh pinnaes in $100 \mathrm{ml} 80 \%$ acetone, with the addition of traces of $\mathrm{MgCO}_{3}$. The absorbance of the clear extract was measured at 663, 646 and 470nm. The concentration of chlorophyll a \& b as well as total caroteniods were calculated as $\mathrm{mg} / 100 \mathrm{~g}$ fresh weight according to the formulae. ${ }^{16}$

$$
\begin{aligned}
& \text { Chl } a=12.21 E_{663}-2.81 E_{646} \quad \mu g m l^{-1} \\
& \text { Chl } b=20.13 E_{646}-5.03 E_{663} \quad \mu g m l^{-1} \\
& \text { Carotenoids }=\frac{1000 E 470-3.27 \mathrm{Chl} a-104 \mathrm{Chl} \mathrm{b} \mu g m l^{-1}}{229}
\end{aligned}
$$

\section{Total anthocyanin}

Total anthocyanin was extracted by homogenization of 1.0 gram from grounded dried pinnaes in $95 \%$ ethanol and $\mathrm{HCl} 1.5 \mathrm{~N}$ (85: $15 \mathrm{v} / \mathrm{v})$ and filtered using vacum pump. The absorbance of the extracted solution was measured at $535 \mathrm{~nm}$. The concentration of total anthocyanin was calculated as $\mathrm{mg} / 100 \mathrm{~g}$ dry weight according to the formulae of. ${ }^{17}$

Total anthocyaninmg/100g. $=$ O.D. ${ }_{535} \times D . V \times 100 / P . W \times 1 / 98.2$

Where O.D. $=$ The optical density of the diluted sample.

D.V. = Diluted volume as the volume in $(\mathrm{ml})$ of the diluted extract prepared for the O.D. measurement.

$$
\text { P.W. = pinnae weight in grams }
$$

\section{Total carbohydrates}

Total carbohydrates $\mathrm{g} / 100 \mathrm{~g}$ dry weight was extracted by sulphuric acid $(67 \%)$ then determined colorimetrically by using phenolsulphuric acid reagent according to the method described by. ${ }^{18}$

\section{Total and reducing sugars}

Total and reducing sugars were determined in ethanolic extract using phosphomolybdic acid reagent as described by, ${ }^{19}$ and calculated as $\mathrm{g} / 100 \mathrm{~g}$ dry weight.

\section{Total free amino acids}

Total free amino acids in fresh pinnae were determined colorimetrically in ethanolic extract using ninhydrin reagent according to the method described by ${ }^{20}$ and calculated as $\mathrm{mg} / \mathrm{g}$ dry weight.

\section{Free proline}

Free proline concentration $(\mathrm{mg} / \mathrm{g}$ dry weight) was extracted by sulfosalicylic acid (3\%) then, determined colorimetrically at $535 \mathrm{~nm}$ using acid ninhydrin and toluene reagent as outlined by. ${ }^{21}$

\section{Total indoles}

Total indoles $\mathrm{mg} / \mathrm{g}$ fresh weight were determined in ethanolic extract using 4-dimethylaminobenzaldehyde reagent as described by. ${ }^{22}$

\section{Total phenols}

Total phenols in fresh pinnae were determined in ethanolic extract using Folin-Denis reagent as described by ${ }^{19}$ and calculated as $\mathrm{mg} / \mathrm{g}$ fresh weight.

\section{Nitrogen \%}

Nitrogen $\%$ in pinnae was determined, using the Orange $G$ dye colorimetric method. ${ }^{23}$

2.1.10. Crude protein Crude protein was calculated by nitrogen $\% \times 5.75$.

\section{Dry matter}

Dry matter of male and female pinnae was determined according to ${ }^{19}$ and expressed as percentage.

\section{Ash and silicon}

Ash and silicon of male and female pinnae were determined according to ${ }^{24}$ Hanna's Method (1964) and expressed as percentage on dry weight basis

\section{Statistical analysis}

Data were statistically analyzed according to. ${ }^{25}$ Data presented in the Table of this investigation represent the mean of the three 
experimental seasons. The differences between means were differentiated by using student's t-test.

\section{Results}

\section{Chemical constituents}

\section{Leaf pigments}

\section{Plastid pigment concentration}

Data recorded in Table $1 \&$ Table 2 clearly show that, pinnae of female trees showed higher values of plastid pigments as compared with those of male trees. The increments reached about 14.72 for chlorophyll a; $23.77 \%$ for chlorophyll b $55.94 \%$ for total caroteniods over the male trees respectively. Thus, it could be concluded that pinnae of plastid pigments could be used as a good parameter in predicting sex in date palm trees.

\section{Cell-sap pigment}

The results obtained in Table 2 indicate that, pinnae of female trees recoded higher values of total anthocyanin in comparison with male trees. The increase was recorded $39.02 \%$ over the male trees.

Table I Chlorophyll a and b concentration of male and female pinnae date palm as the mean of the three seasons studied

\begin{tabular}{|c|c|c|c|c|c|c|c|c|}
\hline \multirow[b]{3}{*}{ No. } & \multicolumn{4}{|c|}{ Chlorophyll a (mg/l00 g F.W.) } & \multicolumn{4}{|c|}{ Chlorophyll b (mg/l 00 g F.W.) } \\
\hline & \multicolumn{2}{|l|}{ Male } & \multicolumn{2}{|l|}{ Female } & \multicolumn{2}{|l|}{ Male } & \multicolumn{2}{|l|}{ Female } \\
\hline & Mean* & C.V**. & Mean* & C.V.** & Mean* & C.V**. & Mean* & C.V** \\
\hline I & 65.15 & 2.1. & 79.25 & .22 & 40.12 & $\ldots 2$ & 51.21 & 1.11 \\
\hline 2 & 68.1 & $8 . .1$ & 78.88 & $8 . .1$ & 43.14 & 8.23 & 51.44 & 1.21 \\
\hline 3 & 66.15 & 5.11 & 78.99 & 5.12 & 41.11 & 8.11 & 49.18 & 3.21 \\
\hline 4 & 63.15 & 8.1. & 75.21 & $1 . .2$ & 41 & $8 . .5$ & 51.89 & 2.58 \\
\hline 5 & 68.21 & .22 & 73.11 & 5.12 & 38.99 &. .82 & 52.15 & 2.85 \\
\hline 6 & 66.18 & 2.11 & 74.26 &. .12 & 42.22 &. .13 & 49.55 & $1 \ldots$ \\
\hline 7 & 67.25 & 5.88 & 74.44 & I..I & 42.15 & $2 . .5$ & 52.18 & .23 \\
\hline 8 & 65.2 & $\ldots$. & 72.51 & $8 . .2$ & 40.13 &. .11 & 51.25 &. .82 \\
\hline 9 & 67.91 & $1 . .2$ & 78.85 &.. .1. & 41.11 & 5.18 & 50.45 & 5.13 \\
\hline 10 & 66.55 & $1 . .3$ & 75.15 &. .15. & 43.52 & 3.21 & 53.01 & 8.52 \\
\hline Mean & 66.3 & $8 . .2$ & 76.06 & 2.11 & 51.85 & 8.23 & $21 . .8$ & 8.33 \\
\hline Sig.5\% & & & $*$ & & & & & $*$ \\
\hline
\end{tabular}

*Mean of seasons, 2015, 2016and 2017

*** Coefficient of variation

Table 2 Total caroteniods and total anthocyanin concentration of male and female pinnae date palm as the mean of the three seasons studied.

\begin{tabular}{|c|c|c|c|c|c|c|c|c|}
\hline \multirow{3}{*}{ No. } & \multicolumn{4}{|c|}{ Total carotenoids(mg/l 00 g F.W.) } & \multicolumn{4}{|c|}{ Total carotenoids(mg/l 00 g F.W.) } \\
\hline & \multicolumn{2}{|l|}{ Male } & \multicolumn{2}{|l|}{ Female } & \multicolumn{2}{|l|}{ Male } & \multicolumn{2}{|c|}{ Female } \\
\hline & Mean* & $\mathrm{C} . \mathrm{V} * *$ & Mean* & C.V.** & Mean* & C.V**. & Mean* & C.V** \\
\hline 1 & 9.38 & 0 & 15.6 & $3 . .8$ & 24.81 & 2.25 & 34.74 & $2 . .2$ \\
\hline 2 & 9.48 & I.I. & 16.24 & $8 . .2$ & 25.48 & 3.65 & 34.87 & 2.33 \\
\hline 3 & 9.72 & $2 \ldots$ & 15.06 &. .15 & 24.62 & 5.39 & 36.18 & 3.22 \\
\hline 4 & 10.61 & 1.23 & 14.68 & 2.58 & 24.43 & 8.21 & 34.38 & $5 . .2$ \\
\hline 5 & 10.8 & .23 & 16.78 & $2 . .8$ & 24.14 & 9.38 & 35.22 & $3 . .3$ \\
\hline 6 & 10.06 & 5.82 & 15.6 & $\ldots 2$ & 25.19 & 6.38 & 35.18 & 2.82 \\
\hline 7 & 9.88 & 2.12 & $|4.5|$ & 2.32 & 24.43 & 9.78 & 33.4 &. .85 \\
\hline 8 & 10.33 & $\ldots 8$ & |5.7| & $\ldots 8$ & 25.34 & 9.64 & 33.26 & 2.85 \\
\hline 9 & 9.69 &. .52 & 15.78 & 3.12 & 25.18 & 9.28 & 36.01 & 2.12 \\
\hline 10 & 10.1 &. .18 & 16.18 & 5.1. & 25.45 & 8.25 & 33.05 &. .15 \\
\hline Mean & 10.01 & $2 . .8$ & $|5.6|$ &.. .1. & .5 .21 &. .83 & $85 . .8$ & $8 . .3$ \\
\hline Sig. $5 \%$ & & & $*$ & & & $*$ & & \\
\hline
\end{tabular}

*Mean of seasons, 2015, 2016and 2017

***oefficient of variation 


\section{Carbohydrates and Sugars concentration}

Data recorded in Table 3 \& Table 4 clearly show that, total carbohydrates, total sugars and reducing sugars concentration were significantly higher in female trees than in male once. The increase recorded $14.34 \%$ for total carbohydrates; $32.61 \%$ for total sugars and $43.37 \%$ for reducing sugars over the male trees respectively. The obtained results in this study showed clearly that carbohydrates could be used safely to predict sex in date palm trees.

Table 3 Total carbohydrates and total sugars concentration of male and female pinnae date palm as the mean of the three seasons studied.

\begin{tabular}{|c|c|c|c|c|c|c|c|c|}
\hline \multirow{3}{*}{ No. } & \multicolumn{4}{|c|}{ Total carbohydrates (g// 00 gD.W.) } & \multicolumn{4}{|c|}{ Total sugars (g/ 100 gD.W.) } \\
\hline & \multicolumn{2}{|l|}{ Male } & \multicolumn{2}{|l|}{ Female } & \multicolumn{2}{|l|}{ Male } & \multicolumn{2}{|l|}{ Female } \\
\hline & Mean * & C.V $* * *$ & Mean* & C.V.** & Mean* & C.V**. & Mean* & C.V** \\
\hline I & 14.21 & $\mathrm{I} \ldots$ & 17.11 & 1.52 & 5.11 &. .12 & 8.82 & $1 . .2$ \\
\hline 2 & 16.33 &. .12 & 16.33 & $1 . .3$ & 6.25 &. .52 & 7.32 & $1 . .2$ \\
\hline 3 & 14.15 &. .53 & 18.45 & $1 . .2$ & 5.41 & $\ldots 2$ & 7.25 & $5 . .2$ \\
\hline 4 & 16.52 & 1.25 & 16.74 & 8.1. & 6.25 &. .13 & 8.01 & 1.82 \\
\hline 5 & 15.25 & 8.1. & 17.44 & 5.1. & 6.97 & $8 . .2$ & 7.99 &. .21 \\
\hline 6 & 15.36 & 8.2 & 18.52 & 5.1. & 6.14 & $8 . .3$ & 7.88 & $5 . .3$ \\
\hline 7 & 15.85 & 5.1. & 18.18 & 8.11 & 5.2 & $8 . .2$ & 8.52 & I.I. \\
\hline 8 & $15.2 \mid$ & $8 \ldots$ & 18.8 &. .12 & 6.36 & 8.1. & 7.35 & 1.21 \\
\hline 9 & 15.66 &. .11 & 16.42 & 8.1. & 5.52 &. .81 & 8.68 & 1.82 \\
\hline 10 & 15.58 &. .23 & 18.25 & $8 . .1$ & 7.14 &. .1. & 8.26 & 1.23 \\
\hline Mean & I5.4I & 8.11 & 17.62 & 2.18 &. .15 &. .12 & 3.11 & 1.133 \\
\hline Sig. $5 \%$ & & & $*$ & & & $*$ & & \\
\hline
\end{tabular}

*Mean of seasons, 2015, 2016and 2017

**Coefficient of variation

Table 4 Reducing sugars and dry matter concentration of male and female pinnae date palm as the mean of the three seasons studied

\begin{tabular}{|c|c|c|c|c|c|c|c|c|}
\hline \multirow{3}{*}{ No. } & \multicolumn{4}{|c|}{ Reducing sugars (g/l 00 gD.W.) } & \multicolumn{4}{|c|}{ Dry matter \% } \\
\hline & \multicolumn{2}{|l|}{ Male } & \multicolumn{2}{|l|}{ Female } & \multicolumn{2}{|l|}{ Male } & \multicolumn{2}{|l|}{ Female } \\
\hline & Mean* & C.V**. & Mean* & C.V.** & Mean* & C.V**. & Mean* & C.V** \\
\hline I & 0.86 & $1 . .2$ & 1.21 &. .12 & 34.52 & $\ldots 2$ & 41.11 &. .8. \\
\hline 2 & 0.83 & I.I. & 1.32 & .23 & 35.15 & $2 . .5$ & 42.01 & 2.58 \\
\hline 3 & 0.87 & 1.82 & 1.01 &. .15 & 37.2 & $8 . .2$ & 40.25 & $2 . .3$ \\
\hline 4 & 0.73 & 1.83 & 1.25 &. .18 & 36.32 & $\ldots 2$ & 41.18 & 2.8. \\
\hline 5 & 0.81 &. .18 & 1.19 & $1 . .2$ & 36.15 &. .85 & 42.15 &. .82 \\
\hline 6 & 0.75 & $2 . .2$ & 1.18 & 1.8 & 37.1 &. .81 & 40.51 &. .8 . \\
\hline 7 & 0.9 & 8.12 & 1.12 & 1.2 & 35.93 & $\ldots 2$ & 41.34 & 2.85 \\
\hline 8 & 0.86 & 8.2 . & 1.14 &. .85 & 37.13 & $\ldots 5$ & 41.02 & 5.8. \\
\hline 9 & 0.88 &. .12 & 1.15 &. .8 & 37.02 &. .8. & 40.25 & 5.12 \\
\hline 10 & 0.8 &. .15 & 1.31 &. .15 & 35.96 &. .52 & 42.33 & 5.8. \\
\hline Mean & 0.83 &. .52 & 1.19 & .23 & $8 \ldots 2$ &... & $51 \ldots$ & $5 . .2$ \\
\hline Sig. $5 \%$ & & $*$ & & & $*$ & $*$ & & \\
\hline
\end{tabular}

*Mean of seasons, 2015,2016 and 2017

**Coefficient of variation 


\section{Dry matter accumulation (\%)}

Data recorded in Table 4 show that, there is a clear relationship between accumulation (\%) dry matter and sex expression of date palm trees. The highest accumulation (\%) from dry matter was obtained with the female pinnae trees. The increase over the male trees was recorded $13.71 \%$ for dry matter accumulation (\%).

\section{Silicon concentration}

Data recorded in Table 5 show that, there is a relationship between pinnae concentration from silicon and sex expression of date palm trees. The highest concentration of pinnae from silicon was obtained with the female trees. The increase over the male trees was recorded $56.86 \%$ for silicon concentration. The obtained results in this study showed clearly that silicon could be used as a guide in forecasting the sex of date palm trees. The obtained results go in line with the findings reported earlier by Bahgat and Brown. ${ }^{8}$ who mentioned that leaves of some female palms cv. Samany and Zaghloul contain higher silicon $\%$ than those of male ones.

Table 5 Silicon and total soluble phenols concentration of male and female pinnae date palm as the mean of the three seasons studied.

\begin{tabular}{lllllllll}
\hline & \multicolumn{3}{l}{ Silicon \% } & \multicolumn{3}{c}{ Total soluble phenols (mg/ g F.W.) } \\
\cline { 2 - 9 } No. & Male & & Female & & Male & \multicolumn{3}{c}{ Female } \\
\cline { 2 - 9 } & Mean* & C.V**. & Mean* & C.V.** & Mean* & C.V**. & Mean* & C.V** \\
\hline 1 & 1.33 & 1.1. & 2 & 1.2 & 3 & $1 . .3$ & 7.48 & $1 . .2$ \\
2 & 1.65 & 1.2 & 2.93 & 1.8. & 4.86 & 1.8. & 7.52 & 1.53 \\
3 & 1.23 & 1.15 & 2.54 & 1.2 & 4.66 & 1.53 & 7.74 & $1 . .2$ \\
4 & 1.65 & 153 & 2.5 & 1.15 & 4.85 & 1.82 & 8 & 1.8. \\
5 & 1.65 & $1 . .8$ & 2.35 & 1.1. & 4.94 &. .81 & 8.52 & $1 . .2$ \\
6 & 1.64 & 1.52 & 2.47 & 1.33 & 3.38 & .23 & 8.33 & $1 . .2$ \\
7 & 1.32 & 1.2 & 2.51 & 1.32 & 3.57 & 1.8. & 8.2 & 1.25 \\
8 & 1.6 & 1.81 & 2.35 & 1.2 & 3.64 & 1.52 & 8.61 & 1.8. \\
9 & 1.55 & 1.23 & 2.6 & 1.82 & 4.99 & $1 . .5$ & 7.99 & $1 . .2$ \\
10 & 1.71 & 1.52 & 2.47 & $1 . .2$ & 3.52 & 1.82 & 7.85 & 1.52 \\
Mean & 1.53 & 1.8. & 2.47 & 1.32 & 5.15 & 1.23 & 8.02 & 1.8. \\
Sig.5\% & & & $*$ & & $*$ & & & \\
\hline
\end{tabular}

*Mean of seasons, 2015, 20I6and $2017 * *$ Coefficient of variation

\section{Total soluble phenols concentration}

Data recorded in Table 5 clearly show that total soluble phenols of pinnae were greatly affected by sex kind of date palm trees. Moreover, the total soluble phenols were significantly increased in female trees as compared to male trees. The maximum increase in total soluble phenols concentration reached $93.71 \%$ respectively over the male trees. The data also show that pinnae concentration from total soluble phenols could be used as indicator in early detection of sex in date palm trees.

\section{Nitrogen and crude protein \%}

Data recorded in Table 6 show that, there is a relationship between pinnae concentration from nitrogen and crude protein and sex expression of date palm trees. The highest concentration from nitrogen and crude protein were obtained with the pinnae of female trees. The increases over the male trees were recorded $48.33 \%$ for nitrogen and $48.98 \%$ for crude protein, respectively.

\section{Total free amino acids concentration}

Data presented in Table 7 indicate that, pinnae of female trees contained a high concentration of total free amino acids as compared to male trees. Moreover, the total free amino acids were significantly increased in female trees. The maximum increase was $10.47 \%$ respectively over the male trees. These results are in harmony with those obtained by Khan et al. ${ }^{4}$ and Dutta and Mazumdar. ${ }^{5}$ in papaya who reported that leaf content of amino acids were higher in pistillate plants as compared with staminate ones.

Table 6 Total nitrogen and crud protein \% concentration of male and female pinnae date palm as the mean of the three seasons studied

\begin{tabular}{|c|c|c|c|c|c|c|c|c|}
\hline \multirow{3}{*}{ No. } & \multicolumn{4}{|c|}{ Total nitrogen (g/l00 g D.W.) } & \multicolumn{4}{|c|}{ Crud protein (g/ 100gD.W.) } \\
\hline & \multicolumn{2}{|l|}{ Male } & \multicolumn{2}{|l|}{ Female } & \multicolumn{2}{|l|}{ Male } & \multicolumn{2}{|l|}{ Female } \\
\hline & Mean* & C.V**. & Mean* & C.V.** & Mean* & C.V**. & Mean* & C. $\mathbf{V} * *$ \\
\hline I & 1.25 & 8.I. & 1.86 & I..2 & 7.18 &. .52 & 10.69 & ।...2 \\
\hline 2 & 1.13 & 8.15 & 1.89 & 1.52 & 6.49 & $8 . .2$ & 10.86 & 1.8. \\
\hline 3 & 1.22 &. .12 & 1.88 & 1.53 & 7.02 & $8 . .2$ & 10.81 & I...2 \\
\hline 4 & 1.18 &. .15 & 1.73 & ... & 6.78 & 8.53 & 9.94 & $5 . .2$ \\
\hline
\end{tabular}


Table Continued....

\begin{tabular}{|c|c|c|c|c|c|c|c|c|}
\hline \multirow{3}{*}{ No. } & \multicolumn{4}{|c|}{ Total nitrogen (g/l00 g D.W.) } & \multicolumn{4}{|c|}{ Crud protein (g/ I00gD.W.) } \\
\hline & \multicolumn{2}{|l|}{ Male } & \multicolumn{2}{|l|}{ Female } & \multicolumn{2}{|l|}{ Male } & \multicolumn{2}{|l|}{ Female } \\
\hline & Mean* & C.V**. & Mean* & C.V.** & Mean* & C.V**. & Mean* & C.V** \\
\hline 5 & 1.15 &. .81 & 1.69 &. .85 & 6.61 & $8 \ldots$ & 9.71 & 8.12 \\
\hline 6 & 1.16 &. .2 & $\mathrm{I} .85$ &. .53 & 6.67 & 5.8. & 10.63 & $5 . .2$ \\
\hline 7 & 1.21 &. .81 & $\mathrm{I} .74$ &. .22 & 6.95 & $5 . .2$ & 10 & ... \\
\hline 8 & 1.25 &. .52 & 1.58 & 5.82 & 7.18 & 2.8 & 9.08 & 8.I. \\
\hline 9 & 1.2 &. .13 & 1.79 &. .12 & 6.9 & 5.12 & 10.29 & $2 . .2$ \\
\hline 10 & 1.22 &. .33 & 1.83 &. .53 & 7.02 &. .82 & 10.52 &. .18 \\
\hline Mean & 1.2 &. .11 & I.78 &. .15 &. .33 &. .11 & II..2 & $8 . .2$ \\
\hline Sig.5\% & & & $*$ & & $*$ & & & \\
\hline
\end{tabular}

*Mean of seasons, 2015, 2016and $2017 * *$ Coefficient of variation

Table 7 Total free amino acids and total indoles concentration of male and female pinnae date palm as the mean of the three seasons studied

\begin{tabular}{|c|c|c|c|c|c|c|c|c|}
\hline \multirow{3}{*}{ No. } & \multicolumn{4}{|c|}{ Total free amino acids (mg/g D.W.) } & \multicolumn{4}{|c|}{ Total indoles (mg/ g F.W.) } \\
\hline & \multicolumn{2}{|l|}{ Male } & \multicolumn{2}{|l|}{ Female } & \multicolumn{2}{|l|}{ Male } & \multicolumn{2}{|l|}{ Female } \\
\hline & Mean* & C.V**. & Mean* & C.V.* & Mean* & C.V**. & Mean* & C.V** \\
\hline I & 12.33 & |...2 & 13.21 &. .12 & 0.71 & $2 \ldots$ & 1.21 & I..2 \\
\hline 2 & 11.55 & 1.82 & 12.52 &. .8. & 0.9 & 5.82 & 1.25 & 8.2 \\
\hline 3 & 12.42 & 1.25 & 13.42 & 5.82 & 0.71 &. .2 & 1.24 & 5.2 \\
\hline 4 & 11.58 & $\ldots 2$ & 13.57 &. .52 & 0.71 & $8 . .2$ & 1.25 &. .82 \\
\hline 5 & 12.21 & 5.82 & 13.58 & 2.85 & 0.94 & I.5. & 1.27 & $8 . .3$ \\
\hline 6 & II.47 & 8.12 & 12.96 & $\ldots$ & 0.88 & $8 . .2$ & 1.25 & 8.28 \\
\hline 7 & 12.12 & I.8. & 12.26 & 5.82 & 0.76 & I.8. & 1.28 & 5.82 \\
\hline 8 & 11.52 & 5.82 & 12.36 & I... & 0.91 &. .12 & 1.25 &. .81 \\
\hline 9 & 11.58 &. .12 & 13.69 & ...8 & 0.78 & 8.52 & 1.21 & 5.8. \\
\hline 10 & 11.62 & 8.12 & 13.58 & 5.8. & 0.79 &. .52 & 1.24 &. .8 \\
\hline Mean & II.84 &. .23 & 13.08 & 8.I. & I.3I & $8 . .2$ & I..5 &. .33 \\
\hline Sig.5\% & & & $*$ & & $*$ & & & \\
\hline
\end{tabular}

*Mean of seasons, 2015, 2016 and $2017 * *$ Coefficient of variation

\section{Total indoles concentration}

Data recorded in Table 7 clearly show that, total indoles of pinnae was significantly higher in female trees than the male trees. The increase was recorded $53.08 \%$ over the male trees. These results are in harmony with those obtained by Salama (1998), in papaya, who pointed out that pistillate plants could be predicted through the higher leaf blade and petiole content of total indoles.

\section{Free proline concentration}

The data in Table 8 reveal that, pinnae of staminate trees showed higher concentration of free proline in comparison with the corresponding ones of pistillate trees. The increase was recorded $19.26 \%$ over the female trees. In this concern, pinnae content of free proline could be used as indicator in early detection of sex in date palm trees. These results are in contrast with that obtained by Salama, ${ }^{7}$ in papaya, who pointed out that pistillate plants could be predicted through the higher leaf blade of free proline.

\section{Ash concentration}

Table 8 indicates that, there is a relationship between pinnae $\%$ of ash and sex expression of date palm trees. In other words, pinnae of male trees recoded higher values of ash in comparison with female trees. The increase was recorded $8.77 \%$ over the female trees. These results are in harmony with those obtained by Helail and Atawia ${ }^{6}$ in papaya, who stated that leaf ash content of male plants was higher than those of female ones. 
Table 8 Free proline and ash concentration of male and female pinnae date palm as the mean of the three seasons studied.

\begin{tabular}{|c|c|c|c|c|c|c|c|c|}
\hline \multirow{3}{*}{ No. } & \multicolumn{4}{|c|}{ Free proline (mg/g D.W.) } & \multicolumn{4}{|l|}{ Ash \% } \\
\hline & \multicolumn{2}{|l|}{ Male } & \multicolumn{2}{|l|}{ Female } & \multicolumn{2}{|l|}{ Male } & \multicolumn{2}{|l|}{ Female } \\
\hline & Mean* & C.V**. & Mean* & C.V.** & Mean* & C.V**. & Mean* & C.V** \\
\hline 1 & 7.71 &. .12 & 7.77 & $8 . .2$ & 8.34 & $8 . .2$ & 7.14 & 8.1. \\
\hline 2 & 8.55 & 5.82 & 7.41 & 8.23 & 8.11 &. .12 & 7.42 & 8.12 \\
\hline 3 & 7.91 & 8.12 & 7.25 & 5.1 & 8.23 & 5.1 & 7.33 &. .12 \\
\hline 4 & 8.88 &. .12 & 7.69 & $\ldots 2$ & 8.15 &. .18 & 7.46 &. .12 \\
\hline 5 & 8.16 & $\ldots 2$ & 7.41 & 5.8. & 7.85 & $\ldots 2$ & 7.61 &. .28 \\
\hline 6 & 9.21 & 5.82 & 7.25 & $5 . .2$ & 7.21 & $8 . .1$ & 7.15 &. .33 \\
\hline 7 & 9.55 & $2 . .2$ & 6.99 & 8.1. & 8.01 & 2.81 & 7.55 &. .53 \\
\hline 8 & 9.85 &. .12 & 7.01 & 8.2. & 8.11 &. .18 & 7.15 & 8.23 \\
\hline 9 & 8.98 &. .1 . & 7.42 &. .25 & 8.52 &. .12 & 7.96 & 8.12 \\
\hline 10 & 9.11 & 8.1. & 7.52 & 3.25 & 8.02 & 8.15 & 7.25 & $8 . .2$ \\
\hline Mean & 8.79 &. .12 & 7.37 & 8.12 & 3.1. & 8.1 . & 3.51 &. .1 . \\
\hline Sig. $5 \%$ & & & $*$ & & N.S. & & & \\
\hline
\end{tabular}

*Mean of seasons, 20I5, 2016 and $2017 * *$ Coefficient of variation

\section{Discussion}

It is clear from the present data that, female date palm trees were characterized by high activity in the anabolic processes as compared to male once, which leads to the accumulation of very important substances that serves in plant metabolism and in predicting sex of date palm (male or female). In this connection, the increase in chlorophyll a \& b as well as total caroteniods in pinnae of female trees may be due to the increase in nitrogen concentration (Table 6) which plays an important role in stimulating chlorophyll synthesis enzymes which reflected on formation of chlorophyll molecule. Moreover, the increase in total anthocyanin in pinnae of female trees may be attributed to the increase in the concentration of sugars in pinnae trees (Table 3). In this respect, ${ }^{26}$ reported that the increase in anthocyanin may be attributed to the increase in the concentration of sugars in plants. The increase in total sugars and carbohydrates concentrations in pinnae female date palm may be directly or indirectly attributed to the effect of certain enzymes that may activate the anabolic processes leading to the accumulation of these substances. Also, the increase in dry matter in pinnae of female trees could be attributed to the stimulating effect of enzymes on chlorophyll formation (Table 1) and consequently photosynthesis which reflected on vegetative growth and physiological processes, i.e. increasing number of cells through cell division and meristematic activity of tissues. The increase in total soluble phenols concentration in pinnae of female trees may be attributed to the increase in metabolic activity in these trees to synthesize shikimic acid. The increase in nitrogen in pinnae of female trees may be attributed to the increase in the concentration of auxin (IAA) (Table 7) which promotes rooting process and consequently the amounts of mineral elements absorbed and translocated into the different parts of the trees. The increase in total indoles in pinnae of female trees may be attributed to the increase in the concentration of total free amino acids (Table 7) especially the synthesis of tryptophan amino acid and consequently in the formation of natural auxin in trees i.e. indole-3- acetic acid (IAA). In this connection, ${ }^{7}$ using papaya, pointed out that pistillate plants could be predicted through the higher leaf blade and petiole content from, total indoles. Moreover ${ }^{13}$ reported that, date palm sap from both male and female trees contained high levels of carbohydrates. HPLC analysis showed that this fraction was dominated by sucrose in the sap sample from female trees compared to that from male trees. Male date palm sap was noted to exhibit lower dry matter content than female date palm sap but higher protein, total polyphenol, ash and amino acid contents. While the major essential amino acids in the sap from male trees consisted of valine and threonine, they were represented by lysine and phenylalanine in sap samples from female trees. Further, Sodium Dodecyl Sulfate Polyacrylamide Gel Electrophoresis (SDS-PAGE) analysis showed the presence of a proteinic band of $30 \mathrm{kDa}$ only for the sap from male trees. Female date palm sap exhibited higher amino acid content than the male palm sap Similar to most plants, the free amino acid pool of both male and female saps was dominated by glutamine, asparagine, ${ }^{27}$ and arginine ${ }^{28}$ In fact, the synthesis of glutamine is the major pathway for the assimilation of ammonium into organic matter, and asparagine represents the major receiver of the nitrogen of glutamine and a mobile reservoir for transport to growth sites. ${ }^{29}$ Arginine, on the other hand, is a precursor of the biosynthesis of polyamines and nitric oxide, which are involved in almost all physiological and biochemical processes as well as in plant growth and adaptation to stress. ${ }^{30}$ The essential amino acids present in male date palm sap were valine and threonine, whereas those present in the female were lysine and phenylalanine. Unlike female date palm sap, male sap does not contain phenylalanine. This last amino acid is a precursor of the biosynthesis of salicylic acid, one of the major phytohormones involved in sex determination. ${ }^{31}$ In fact, different phytohormones are implicated in this process, and the same phytohormone can have varying effects depending on the plant. For example, while Gibberellic acid has a masculinizing effect in Solanum carolinense, Asparagus offcinalis, Cori andrium sativum, Cannabissativus, and Spinacia oleracea, it has a feminizing effect in Luffa acutangula, Hyoscyamus niger and Zea mays. ${ }^{31}$ Accordingly, the results presented in this work suggest that salicylic acid is feminizing in date palm. 
Finally, from the present results, it could be concluded that ,female date palm trees could be predicted through the higher pinnae content from chlorophyll a \& b ,total caroteniods, anthocyanin, total carbohydrates, total sugars, reducing sugars, dry matter, silicon, total free amino acids and total indoles,. On the other hand, early detection of male trees could be forecasted through higher pinnae content from ash and proline.

\section{Acknowledgments}

None.

\section{Conflicts of interest}

Author declares that there is no conflict of interest

\section{References}

1. Chao CCT, Krueger RR. The Date Palm (Phoenix dactylifera L.): Overview of Biology, Uses, and Cultivation. HortScience. 2007;42:10771082.

2. Ahmed DM, Ashour NE, Mostafa EAM, et al.Yield and fruit quality of Amhat date palms as affected by spraying some vitamins. Journal of Applied Sciences Research. 2012;8:4922-4926.

3. Bekheet SA, Hanafy MS. Towards sex determination of date palm. Chapter from book Date Palm Biotechnology. 2011;551-566.

4. Khan MAA, Rahman MA, Uddin MN, et al. Observation on amino acid contents in male and female papaya lants. Bangladesh Horticulture. 1982;10:24-29.

5. Dutta PK, Mazumdar BC. Studies on the protein content of male and female papaya (Carica papaya L.) trees. South India Horticulture. 1989;37:590-595.

6. Helail BM, Atawia AAR. Sex expression of papaya plants in relation to some leaf chemical constituents. Egypt J Appl Sci. 1990;5:130-137.

7. Salama ASM. Studies on growth and flowering of papaya. M.Sc. Thesis Fac. Agric. Moshtohor, Zagazig Univ.

8. Bahgat M, Brown TW. Dates of Egypt. Bull. 24, Hort Dept Ministry of Agric, A.R.E; 1958.

9. El-yazal MA. Sex determination of date palm (Phoenix dactylifera L.) through chemical composition of leaves. Fayoum J Agric. 2008;22:7687.

10. Ben TI, Besbes S, Attia H. Physicochemical characteristics of date sap 'lagmi' from deglet nour palm (Phoenix Dactylifera L.). International Journal of Food Properties. 2009;12:659-670.

11. Makhlouf GI, Mokni GA, Bchir B. Foamability and foam stability of male and female date palm sap (Phoenix dactylifera L.) during the collection period. Food Biophysics. 2015;10:360-367.

12. Makhlouf GIM, Abir Ghribi M, Attia H, et al. Characteristic profiles of an original drink sap from male and female deglet nour palm (Phoenix dactylifera L.) during collection period. International Journal of Agronomy. 2016;1:1-8.

13. Makhlouf GIM, Ghribi MA, Attia H, et al. Physico-chemical properties and amino acid profles of sap from Tunisian date palm. Sci Agric. 73:8590.
14. Rao PVKJ, Das M, Das SK. Changes in physical and thermo-physical properties of sugarcane, palmyra-palm and date-palm juices at different concentration of sugar. Journal of Food Engineering. 209;90:559-566.

15. Dalibard C. Overall view on the tradition of tapping palm trees and prospects for animal production. Livestock Research for Rural Development. 1999;11:1.

16. Welburn AR, Lichtenthaler H. Formula and program to determine total caroteniods and chlorophyll a and b of leaf extracts in different solvents. In Advances in Photosynthesis Research. 1984;2:9-12.

17. Fuleki I, Francis FJ. Quantitative methods for anthocyanins. 1- Extraction and determination of total anthocyanin in Garnberries. $J$ of Food Sci. 1968;33:72-77.

18. Herbert D, Phipps PJ, Strange RF. Determination of total carbohydrates. Methods in Microbian. 1971;5:209-244.

19. A.O.A.C. Official methods of analysis of the association of official agricultural chemists. Sixteenth ed., Washington DC, USA. 1995.

20. Jayarman J. Laboratory Manual in Biochemistry. Wiley Eastern Limited. New York. 1981;61-73.

21. Bates LS, Waldren RP, Tearc ID. Rapid determination of free proline for water stress studies. Plant and Soil. 1973;39:205-207.

22. Larson P, Harbo A, Klunsour S, et al. On the biogenesis of some indole compounds in Acetobacter xylimum. Physiology Plantarum. 1962;15:552-565.

23. Hafez A, Mikkelsen DS. Colorimetric determination of nitrogen for evaluating the nutritional status of rice. Cоттпи Soil Sci and plant analysis. 1981;12:61-69.

24. Hanna JW. Method for chemical analysis of soil. In: Chemistry of the soil. Firman E, editor. 2nd Oxford, IBB Pubishing Co. New Delhi Bombay Callcuta. 1964;474-480.

25. Snedecor GW, Cochran WG. Statistical Methods.7th ed, Iowa State Univ. press, Ames, Iowa, USA.

26. El-Yazal MA, Abd El-Samie FS. Phyiological studies on the effect of weed control treatments on growth,yield and some chemical constituents of broad bean (Vicia faba L.) plants.Annals of Agric Sci Moshtohor. 2002;40:199-221.

27. Fischer WN, André B, Rentsch D, et al. Amino acid transport in plants Trends in Plant Science. 3:188-195.

28. Salaün M, Charpentier S. Rapid analysis of organic and amino acids by capillary electrophoresis: application to glutamine and arginine contents in an ornamental shrub. Journal of Plant Physiology. 2001;158:1381-1386.

29. Joy KW. Ammonia, glutamine and asparagine: a carbon-nitrogen interface. Canadian Journal of Botany. 1998;66:2103-2109.

30. Yang HQ, Gao HJ. Physiological function of arginine and its metabolites in plants. Journal of Plant Physiology. 33:1-8.

31. Golenberg EM, West NW. Hormonal interactions and gene regulation canlink monoecy and environmental plasticity to the evolution of dioecy in plants. American Journal of Botany. 2013;100:1022-1037. 